\title{
PRODUKTIVITAS PERSILANGAN AYAM KAMPUNG DAN AYAM RAS LEGHORN STRAIN ISA BROWN
}

\author{
S. DAKO ${ }^{1}$, F. ILHAM ${ }^{1}$, N. K. LAYA ${ }^{1}$, S. FATHAN ${ }^{1}$, S. MASILI ${ }^{2}$, M. DAN M. AZAR ${ }^{2}$ \\ ${ }^{1}$ Department of Animal Husbandry, Faculty of Agriculture, State University of Gorontalo. \\ ${ }^{2}$ Student of Department of Animal Husbandry, Faculty of Agriculture, State University of Gorontalo. \\ E-mail: sdako@ung.ac.id
}

\section{ABSTRACT}

This study aims to determine the productivity of crosses of native chickens and Leghorn chickens strain Isa brown. This study used 3 male native chickens aged 12-24 months and 28 female Leghorn, weighing 1100-1200 grams, livestock marriage by artificial insemination, sperm dilution 1:4. The results of this study illustrate volume of semen: 0.25 $\pm 0.01-0.26 \pm 0.06$, semen $p H:$ : 6.46 $\pm 0.15-6.50 \pm 0.19$, semen color is white, egg weight: 51.50-54.17 grams, egg index: 0.76-0.79\%, egg fertility 65,70-78.00\%, hatchability 76.83-78.75\% hatching weight: $39.34-39.39$ gram. In conclusion: $0.25 \pm 0.03$, semen $\mathrm{pH}$ : $6.48 \pm 0.19$, semen color is white, egg weight 52.42 eggs, egg index 0.78 , fertility eggs $74.43 \%$. hatchability $77.93 \%$, and $F 1$ weight 1 day from ege: 39.37 grams, and DOC heritability weight 0.43 .

\section{PENDAHULUAN}

Ayam lokal (kampung) merupakan sumber plasma nutfah atau sumber genetik unggas dengan populasi terbanyak dibanding unggas lokal lain dan penyebaran luas di seluruh wilayah serta keragamannya sesuai dengan potensi wilayahnya. Ayam lokal berperanan sebagai penghasil telur maupun daging setelah ayam ras, walaupun kemampuan produksi telur dan daging dari ayam lokal tersebut rendah dibandingkan dengan ayam ras petelur maupun pedaging, tetapi harga jual produk ayam lokal baik telur maupun dagingnya lebih mahal dibandingkan produk yang sama yang dihasilkan oleh ayam ras. Kelebihan ayam lokal juga dapat memanfaatkan pakan bernutrisi rendah dan tahan terhadap perubahan lingkungan dan penyakit.

Keberadaan ayam lokal Gorontalo atau ayam kampung asli Gorontalo juga merupakan merupakan salah satu jenis ternak lokal yang mempunyai potensi ekonomi sangat besar. Ternak ayam kampung dimiliki hampir disetiap keluarga di pedesaan. Permasalahan utama ayam kampung adalah produktivitas rendah, pertumbuhan lambat, produksi telur rendah, lambatnya perkembangan ayam kampung disebabkan rendahnya mutu genetik yang dimilikinya. Hal ini didukung dengan beberapa hasil penelitian bahwa pemeliharaan intensif untuk ayam kampung super pada umur 60 hari mencapai bobot badan rata-rata sebesar 0,85 kg, sedangkan ayam kampung tetuanya hanya $0,50 \mathrm{~kg}$ (Muryanto, 2005). Bobot badan rata-rata ayam kampung asli yang dipelihara sampai umur 10 minggu hanya mencapai $683,58 \mathrm{~g}$ dan rata-rata bobot badan ayam kampung super mencapai 0,8 -1,0 kg pada umur 9 minggu.

Lambatnya pertumbuhan ayam kampung asli disebabkan rendahnya mutu genetik yang dimilikinya, rataan penambahan bobot badan per minggu pada enam bulan pertama $26 \mathrm{~g}$ untuk jantan dan $25 \mathrm{~g}$ untuk betina (Prasetyo dkk., 2002). Ayam kampung yang berasal dari Bone-Bolango Provinsi Gorontalo memiliki bobot tubuh 1-2 kg, diumur 1-2 tahun dan memiliki fenotipe warna bulu beragam: hitam, putih, coklat, merah hitam dan kombinasinya (Aliansyah dkk., 2015; Srivin dkk., 2015).

Untuk dapat menghasilkan ternak ayam kampung yang memiliki pertumbuhan yang cepat, umur potong 
cepat, dan ketersediaan bibit berkesinambungan sehingga dapat memenuhi permintaan pasar, dapat dilakukan dengan peningkatan produktivitas melalui seleksi dan persilangan dengan introduksi genetik ayam ras untuk memacu pertumbuhan anak ayam hasil silangannya, dengan program perkawinan triple crossing dengan breed yang lain. Upaya perbaikan dan peningkatan, sifat pertumbuhan, sifat produksi dan reproduksi ayam kampung guna menghasilkan ayam kampung unggul, telah dilakukan langkah awal penelitian tentang "Produktivitas persilangan ayam kampung dengan ayam leghorn betina tipe Isa Brown".

$\begin{array}{ccr}\text { Tujuan } & \text { utama penelitian: } \\ \text { "Produktivitas } & \text { Persilangan } & \text { Ayam }\end{array}$ Kampung dengan Ayam Leghorn Betina Tipe Isa Brown", guna dijadikan induk untuk penelitian selanjutnya.

\section{MATERI DAN METODE}

Penelitian ini dilaksanakan di Laboratorium Peternakan, Fakultas IlmuIlmu Pertanian, Universitas Negeri Gorontalo.

\section{Prosedur penelitian}

Penelitian ini menggunakan 3 ayam kampung jantan (umur 12-24 Bulan) dan 28 ekor ayam Leghorn betina (umur 14 bulan, bobot badan ayam 1100-1200 gram). Penempatan ternak ayam didalam kandang baterei masing-masing 1 ekor/flok.

Perkawinan pada ayam dengan cara Inseminasi Buatan (IB). Pengambilan sperma dari ayam jantan dilakukan pada sore hari (15.00-selesai). Ejakulasi pada ayam jantan dilakukan teknik pengurutan: mengurut lembut dari pangkal paha atas hingga ke pangkal ekor hingga dengan cara beraturan. Inseminasi buatan dilakukan di siang hari pukul 15.00-16.00 WITA setelah ternak selesai bertelur, diulang kembali di hari ke-3 berikutnya. Penampungan sperma menggunakan tabung reaksi berukuran $10 \mathrm{~mL}$. Pengenceran sperma menggunakan $\mathrm{NaCl}$ fisiologis dengan perbandingan 1:4. Pengumpulan telur tetas dilakukan setiap hari, telur diseleksi berdasarkan bentuk fisik telur, memasukkan telur tetas kedalam mesin tetas dilakukan di hari ke7, dan untuk menjaga kekurangan data dalam penelitian proses penetasan dilakukan sebanyak 3 periode penetasan.

\section{Analisis Data}

Analisis yang digunakan untuk setiap parameter dalam penelitian ini menggunakan statistik deskriptif (Hanafiah, 1997).

Parameter yang diukur dalam penelitian ini adalah menghitung:

1. Indeks telur

Indeks Telur $=\frac{\text { Panjang telur }}{\text { Lebar telur }} \times 100$

2. Fertilitas telur

Fertilitas telur $=\frac{\text { Telur fertil }}{\mathrm{Jmlh} \text { telur ditetaskan }} \times 100 \%$

3. Daya tetas

Daya tetas $=\frac{\text { Telur menetas }}{\mathrm{Jmlh} \text { telur fertil }} \times 100 \%$

\section{Nilai Heritabilitas F1}

Untuk menghitung seberapa besar nilai pewarisan sifat-sifat produksi dan reproduksi ayam kampung hasil persilangan metode Fulshib correlation dan Halfshib correlation dengan pengaturan pola tersarang (Nested design).

\section{HASIL DAN PEMBAHASAN}

\section{Kualitas Sperma Pejantan}

Berdasarakan hasil penelitian ini kualitas sperma (secara makroskopis) disajikan pada Tabel 1.

\section{Volume Semen}

Hasil penelitian menggambarkan volume semen masing-masing kelompok ayam kampung lokal adalah 0,26 $\pm 0,06$; 
$0,26 \pm 0,04$ dan $0,25 \pm 0,01$. Hal ini sejalan dengan penelitian Sturkie (1976) disitasi Johari dkk. (2009) dinyatakan volume semen ayam berkisar 0,11-1 mL. Menurut Nurfirman (2001), faktor yang memengaruhi volume semen yang bervariasi yaitu perbedaan bangsa, umur, ukuran badan, tingkatan makanan, frekuensi penampungan dan metode penampungan.

\section{Warna Semen}

Warna semen pejantan ayam kampung dalam penelitian ini di masing kelompok berwarna putih bersih. Warna semen menentukan konsentrasi spermatozoa, apabila spermatozoa berwarna putih pekat maka konsentrasi spermatozoa tinggi sedangkan semen yang berwarna bening maka konsentrasinya rendah (Sopiyana dkk., 2016).

Tabel 1. Rataan kualitas semen pejantan ayam kampung

\begin{tabular}{ccccc}
\hline Kualitas sperma & A & B & C & Rataan \\
\hline Volume & $0,26 \pm 0,06$ & $0,26 \pm 0,04$ & $0,25 \pm 0,01$ & $0,25 \pm 0,03$ \\
Warna & Putih & Putih & Putih & Putih \\
pH & $6,50 \pm 0,19$ & $6,46 \pm 0,15$ & $6,49 \pm 0,25$ & $6,48 \pm 0,19$ \\
\hline
\end{tabular}

Berdasarkan Tabel 1, derajat keasaman semen pejantan ayam kampung tiap kelompok: $6,46 \pm 0,15 ; 6,49 \pm 0,25$ dan $6,50 \pm 0,19$. Hal ini menggambarkan tidak ada perbedaan derajat keasaman semen pada masing-masing kelompok pejantan. Menurut Toelihere (1985) derajat keasaman $(\mathrm{pH})$ semen dipengaruhi proses metabolisme spermatozoa dalam keadaan anaerobik. Hasil akhir dari proses metabolisme spermatozoa tersebut berupa asam laktat. Semakin tinggi asam laktat yang dihasilkan akan menyebabkan penimbunan yang pada akhirnya dapat menyebabkan meningkatkan derajat keasaman atau menurunkan $(\mathrm{pH})$ larutan tersebut.

\section{Bobot Telur Induk}

Hasil penelitian ini memberikan gambaran bobot telur yang dihasilkan dalam penelitian ini adalah 51,50-54,17 gram dengan nilai rata-rata bobot telur 52,42 gram/ekor, seperti ditunjukkan pada Tabel 2.

Tabel 2. Rataan bobot telur persilangan antara ayam kampung jantan dengan ayam leghorn parent stock strain Isa Brown

\begin{tabular}{cccc}
\hline Jantan/Betina & A & B & C \\
\hline 1 & 52,10 & 53,90 & 52,26 \\
2 & 52,92 & 54,95 & 48,10 \\
3 & 56,00 & 50,90 & 48,50 \\
4 & 48,50 & 51,70 & 53,25 \\
5 & 53,00 & 51,75 & 53,83 \\
\hline Total & 262,53 & 263,20 & 254,94 \\
\hline Rata-rata & 52,51 & 52,64 & 50,99 \\
\hline Stdev & 1,68 & 1,70 & 1,51 \\
\hline
\end{tabular}

Bobot telur yang dihasilkan dalam penelitian ini lebih berat jika dibandingkan telur ayam kampung bobot telur rata-rata 40,09 gram (Natawijaya dkk., 2006). Perbedaan sifat bobot telur ini disebabkan oleh perbedaan genetik dan jenis ayam. Ayam yang memiliki bobot badan besar akan menghasilkan telur yang besar. Menurut Lestari dkk. (1994) bobot telur dapat digunakan sebagai indikator bobot tetas, dimana telur lebih berat akan menghasilkan DOC yang lebih berat. Wardiny (2002) berpendapat bahwa bobot 
telur berat dan besar akan menghasilkan bobot tetas yang yang lebih besar dibandingkan dengan telur yang kecil, tetapi telur yang besar akan menetas lebih lambat, tetapi tidak selamanya bobot telur berkorelasi positif dengan bobot tetas, jika telur yang ditetaskan disimpan lebih dari tujuh hari. Hal ini disebabkan adanya penguapan cairan dari dalam telur, sehingga bobot telur menjadi turun.

\section{Indeks Telur}

Berdasarkan Tabel 3, indeks telur yang dihasilkan dalam penelitian ini berkisar antara 0,76-0,79\%.

Tabel 3. Rataan indeks telur persilangan ayam kampung jantan dengan ayam leghorn strain Isa Brown

\begin{tabular}{cccc}
\hline Jantan/Betina & A & B & C \\
\hline 1 & 0,76 & 0,77 & 0,77 \\
2 & 0,79 & 0,75 & 0,77 \\
3 & 0,79 & 0,77 & 0,79 \\
4 & 0,82 & 0,75 & 0,80 \\
5 & 0,81 & 0,77 & 0,78 \\
\hline Total & 3,97 & 3,81 & 3,92 \\
\hline Rata-rata & 0,79 & 0,77 & 0,78 \\
\hline Stdev & 0,02 & 0,01 & 0,01 \\
\hline
\end{tabular}

Indeks telur ayam persilangan antara ayam kampung jantan dengan ayam leghorn strain Isa Brown pada masingmasing kelompok pejantan ayam kampung adalah 0,79\%; 0,77\% dan 0,78\%. Hasil ini menunjukkan indeks telur masing-masing kelompok pejantan ayam kampung adalah sama. Indeks telur hasil penelitian ini lebih besar jika dibandingkan dengan keturunan ayam kampung yakni: Indeks telur telur ayam Arab Silver dan Gold masing-masing yaitu $0,74 \pm 3,18 \%$ dan $0,74 \pm 3,19 \%$ (Prasetyo dkk., 2002). Bell and Weaver (2002) menyatakan bahwa indeks telur diperoleh dari hasil pengukuran panjang dan lebar telur (lebar/panjang x 100\%) dan kisaran indeks telur yang normal adalah 0,70-0,74. Butcher dan Miles (2003) menyebutkan, semakin tinggi indeks telur maka kualitas telur semakin baik. Bentuk telur adalah oval, dan tedapat bagian lancip dan tumpul pada kedua ujungnya. Berat telur yang berbeda dipengaruhi oleh beberapa faktor yaitu umur, pakan, dan genetik. Perbedaan bentuk ini umumnya disebabkan karena berbagai faktor, terutama yang berhubungan dengan induknya. Faktor-faktor tersebut adalah genetis, umur ayam pada saat bertelur dan sifat-sifat fisiologis didalam tubuh induk (Warwick dkk., 1990).

\section{Bobot tetas F1}

Berdasarkan hasil penelitian ini dihasilkan bobot tetas telur berkisar antara 39,34 - 39,39 gram (Tabel 3).

Bobot tetas yang dihasilkan dari ketiga kelompok ayam adalah 39,34 gram, 39,39 gram, 39,35 gram dan nilai rata-rata bobot tetas sebesar 39,36 gram. Bobot tetas dipengaruhi oleh bobot telur, saat penelitian rata-rata bobot telur adalah 52,04 gram. Kondisi ini menggambarkan bobot tetas yang dihasilkan berkisar 75,63\% dari bobot telur. Menurut Kurtini (1988), bobot tetas dipengaruhi oleh bobot telur. Telur dengan bobot rata-rata atau sedang akan menetas lebih baik dari pada telur yang berbobot kecil atau terlalu besar. Hal ini karena telur-telur yang lebih besar memerlukan waktu yang lebih lama untuk menetas dibandingkan dengan telur-telur yang lebih kecil. Hal ini di sesuai hasil penelitian Wineland (2000) menyebutkan bahwa bobot telur digunakan sebagai indikator bobot tetas. 
Tabel 3. Rataan bobot tetas persilangan antara ayam kampung jantan dengan ayam leghorn strain Isa Brown

\begin{tabular}{cccc}
\hline Jantan/Betina & A & B & C \\
\hline 1 & 39,36 & 39,22 & 39,36 \\
2 & 39,41 & 39,64 & 39,64 \\
3 & 39,49 & 39,76 & 39,18 \\
4 & 39,56 & 39,53 & 39,56 \\
5 & 38,87 & 38,79 & 39,02 \\
\hline Total & 196,69 & 196,94 & 196,77 \\
\hline Rata-Rata & 39,34 & 39,39 & 39,35 \\
Stdev & 0,27 & 0,39 & 0,26 \\
\hline
\end{tabular}

Bobot telur yang lebih tinggi akan menghasilkan bobot tetas yang lebih besar. Hal ini didukung oleh hasil penelitian Hermawan (2000), yang menyatakan bahwa ada hubungan yang sangat nyata antara bobot telur dan bobot tetas, semakin tinggi bobot telur yang ditetaskan akan menghasilkan bobot tetas yang lebih besar.

\section{Fertilitas telur}

Berdasarkan Tabel 4, fertilitas telur persilangan antara ayam kampung jantan dengan ayam leghorn parent stock strain Isa Brown adalah $74,18 \%$.

Tabel 4. Fertilitas telur persilangan antara ayam kampung jantan dengan ayam leghorn parent stock strain ISA Brown

\begin{tabular}{ccccc}
\hline Jantan/Betina & A & B & C & Total \\
\hline 1 & 77,00 & 66,00 & 70,50 & \\
2 & 73,88 & 75,88 & 75,40 & \\
3 & 74,00 & 76,74 & 75,60 & \\
4 & 76,10 & 73,00 & 76,40 & \\
5 & 74,55 & 74,56 & 73,44 & \\
\hline Total & 376 & 366 & 371 & 74,18 \\
Rata-rata & 75,11 & 73,18 & 74,27 & \\
Stdev & 1,02 & 1,63 & 1,26 & \\
\hline
\end{tabular}

Hasil penelitian ini lebih rendah dibandingkan dengan yang dilaporkan oleh Prawirodigdo dkk. (2001) bahwa fertilitas telur ayam hasil persilangan antara ayam kampung jantan dengan ayam petelur betina mencapai $85 \%$, sedangkan telur hasil persilangan sesama ayam kampung hanya 70\%.

Rendahnya fertilitas telur dalam penelitian ini disebabkan oleh perbedaan pejantan, karena pejantan yang digunakan merupakan ayam kampung lokal milik masyarakat, dan seleksi hanya dilakukan berdasarkan bobot badan. Fertilitas telur di pengaruhi oleh jenis ayam, umur ayam jantan dan betina, pakan, pengelolaan telur sebelum dimasukkan dalam mesin tetas otomatis, perlakuan terhadap ayam ras petelur setelah di IB (Rukmana, 2013).

Presentase fertilitas telur pada penelitian ini lebih tinggi jika dibandingkan hasil penelitian Putri dkk. (2014) tentang persilangan ayam kampung dan ayam broiler dengan sistem perkawinan alami yang fertilitas telurnya hanya $61,87 \%$.

Tingginya tingkat fertilitas ini disebabkan ternak yang digunakan dalam penelitian Putri (2014) menggunakan 
ayam broiler. Ayam broiler yang dipelihara secara intensif bertujuan produksi daging dan akan mempengaruhi saluran reproduksi sebagai akibat penimbunan lemak tubuh, sehingga perjalanan sperma dalam alat reproduksi terhambat dan tidak terjadi fertilitas.

Pengaruh lain terhadap fertilitas telur yang rendah adalah saat inseminasi pada ayam dilakukan tidak tepat pada saluran reproduksi betina sehingga proses perjalanan sperma melalui alat reproduksi betina lebih lambat menuju ovum. Menurut Sastrodiharjo (1996) teknik IB pada ayam buras adalah suatu teknik mengawinkan secara buatan dengan memasukkan semen yang telah diencerkan dengan pengenceran tertentu ke dalam saluran reproduksi ayam betina yang sedang bertelur. Sastrodihardjo (1996) mengemukakan metode pelaksanaan inseminasi buatan pada ayam buras yaitu metode deposisi semen intra vaginal yakni pendeposisian sperma disuntikkan ke dalam vagina dengan kedalaman $\pm 3 \mathrm{~cm}$. Metode deposisi semen intra uterine, artinya pendeposisian sperma disuntikkan ke dalam daerah perbatasan antara vagina dengan bagian uterus atau utero vaginal junction (UVJ) dengan kedalaman $\pm 7-8 \mathrm{~cm}$.

\section{Daya Tetas}

Daya tetas telur yang tinggi merupakan parameter keberhasilan suatu pembibitan unggas, menggambarkan kemampuan dari embrio untuk menetas. Berdasarkan Tabel 5, daya tetas telur ayam hasil perkawinan antara ayam kampung dengan ayam leghorn dalam setiap populasi adalah $76,83 \% ; 78,21 \%$ dan $78,75 \%$ dengan nilai rata-rata $77,93 \%$.

Tabel 5. Daya tetas telur persilangan antara ayam kampung jantan dengan ayam leghorn parent stock strain Isa Brown

\begin{tabular}{ccccc}
\hline Jantan/Betina & A & B & C & Total \\
\hline 1 & 76,50 & 76,20 & 79,00 & \\
2 & 77,80 & 80,64 & 80,60 & \\
3 & 78,00 & 76,74 & 78,64 & \\
4 & 76,30 & 79,10 & 79,53 & \\
5 & 75,55 & 78,35 & 76,00 & \\
\hline Total & 384,5 & 391,03 & 393,77 & $1.168,95$ \\
\hline Rata-rata & 76,83 & 78,21 & 78,75 & 77,93 \\
Stdev & 1,48 & 1,62 & 1,97 & 0,99 \\
\hline
\end{tabular}

Daya tetas dalam penelitian ini memiliki standar deviasi di masingmasing pejantan 1,18-1,97. Hal ini menggambarkan rentang keragaman daya tetas dari masing masing pejantan adalah 0,99 . Faktor-faktor yang mempengaruhi daya tetas yaitu teknis pada waktu memilih telur tetas atau seleksi telur tetas (bentuk telur, bobot telur, keadaan kerabang, ruang udara didalam telur, dan lama penyimpanan) dan teknis operasional dari petugas yang menjalankan mesin tetas (suhu, kelembapan, sirkulasi udara dan pemutaran telur), telur yang kotor dan banyak mengandung mikroorganisme. (Pattison 1993; Srigandono, 1997).

\section{Heritabilitas}

Nilai heritabilitas bobot tetas dalam penelitian ini disajikan pada Tabel 6 . 
Tabel 6. Nilai heritabilitas bobot tetas berdasarkan halfsib correlation

\begin{tabular}{ccccc}
\hline \multirow{2}{*}{ Jantan/betina } & \multicolumn{5}{c}{ h2 } \\
\cline { 2 - 5 } & A-B-C & A-B & A-C & B-C \\
\hline 1 & 0,26 & 0,34 & 0,26 & 0,26 \\
2 & 0,24 & 0,34 & 0,24 & 0,24 \\
3 & 0,58 & 0,36 & 0,49 & 0,69 \\
4 & 0,58 & 0,60 & 0,49 & 0,48 \\
5 & 0,60 & 0,68 & 0,49 & 0,59 \\
\hline Total & 2,26 & 2,32 & 1,97 & 2,26 \\
\hline Rata-rata & 0,45 & 0,46 & 0,39 & 0,45 \\
Stdev & 0,18 & 0,16 & 0,13 & 0,20 \\
\hline
\end{tabular}

Berdasarkan Tabel 6, nilai heritabilitas bobot telur berdasarkan korelasi halfsib antar masing-masing pejantan yang digunakan adalah 0,39-0,46. Hal ini menggambarkan sifat bobot tetas yang diturunkan pada generasi berikutnya bervariasi berdasarkan keragaman pejantan yang digunakan. Dalam penelitian ini pejantan yang digunakan adalah ayam kampung yang berasal dari 4 lokasi yang berada di Kabupaten BoneBolango, sehingga memiliki keragaman yang berbeda. Pejantan tersebut tidak memiliki hubungan kekerabatan, sedangkan seleksi pejantan berdasarkan bobot badan dan umur.

Penelitian ini juga menggambarkan nilai heritabilitas bobot tetas ayam hasil persilangan antara ayam kampung dan ayam leghorn strain isa brown termasuk dalam kategori tinggi, hal ini dipengaruhi Kategori besar kecilnya nilai heritabilitas, yaitu: $h^{2}<0,20$ rendah; 0,20-0,40 sedang dan $>0,40$ tinggi (Warwick dkk., 1990) Nilai heritabilitas yang tinggi disebabkan adanya penggaruh penggabungan genetik dari 2 jenis ayam berbeda yang menurunkan sifat dominan dari masingmasing tetua. Menurut Falconer (1981), kemampuan gabung efek genetik-aditif, mencerminkan dominansi, dominansi $x$ genetik, dan dominansi $\times$ interaksi efek dominansi, jika terjadi kecocokkkan gen maka akan diwariskan pada keturunannya (keturunan hibrid)

\section{KESIMPULAN}

Berdasarkan hasil penelitian ini menggambarkan produktivitas persilangan antara ayam kampung dan ayam leghorn strain Isa Brown menghasilkan semen pejantan ayam kampung sebanyak 0,25 $\pm 0,03$ $\mathrm{mL}$ /ejakulasi, warna semen berwarna putih bersih, $\mathrm{pH}$ semen $6,48 \pm 0,19$. Bobot telur hasil persilangan adalah 52,42 gram/ekor, indeks telur berkisar antara 0,76-0,79, bobot tetas adalah 39,15, fertilitas $74,18 \%$ daya tetas $77,93 \%$ dan heritabilitas bobot tetas 0,43 .

\section{DAFTAR PUSTAKA}

Aliansyah, S. Dako, dan F. Ilham. 2016. Sifat kualitatif ayam kampung di pesisir pantai selatan Kabupaten Bone-Bolango Provinsi Gorontalo. Jurnal Belibis Sains. 1 : 1-5.

Bell and Weaver. 2002. Commercial Chicken Meat and Egg. Kluwer Academic Publisher. United State of America.

Butcher, G.D. and R.D. Miles. 2003. Concepts of Eggshell Quality. University of Florida. University of Florida.

Hanafiah K.A. 1997. Rancangan Percobaan, Teori dan Aplikasi. PT. Raja Grafindo Persada. Jakarta

Hermawan, A. 2000. Pengaruh bobot dan indeks telur terhadap jenis kelamin anak ayam kampung pada saat menetas. Skripsi. Fakultas Peternakan. Institut Pertanian Bogor. Repository IPB. Bogor.

Indrawati, E., T. Saili, S. Rahadi dan L.O. Nafiu. 2015. Fertilitas, daya hidup embrio, daya tetas dan bobot tetas 
telur ayam ras hasil inseminasi buatan dengan ayam tolaki. Jurnal Ilmu dan Teknologi Peternakan Tropis, 1(3) : 32-44.

Johari, S., Y.S. Ondho, S. Wuwuh, Y.B. Henry dan Ratnaningrum. 2009. Karakteristik dan Kualitas Semen Berbagai Galur Ayam Kedu. Fakultas Peternakan Universitas Diponegoro. Diseminarkan dalam Seminar Nasional Kebangkitan Peternakan pada tanggal 20 Mei 2009 di Semarang.

Kurtini, T. 1988. Pengaruh Bentuk dan Warna Kulit Telur Terhadap Daya Tetas dan Sex Ratio Itik Tegal. Tesis. Pascasarjana. Universitas Padjadjaran. Bandung.

Lestari, Ismoyowati dan Sukardi, 1994. Korelasi antara bobot telur dengan bobot tetas dan perbedaan susut tetas pada telur Entok (carrina maschatta) dan itik (Anas plathyrhicas). Jurnal Ilmu Peternakan 1(1) 163-169, Fakultas Peternakan Jenderal Soedirman. Pruwokerto, Banyumas

Maryanto. 2005. Evaluasi Hasil-Hasil Penelitian dan Pengembangan Peternakan pada Ayam Buras dalam Prosiding Lokakarya Nasional Inovasi Teknologi Pengembangan Ayam Lokal. Pusat Penelitian dan Pengembangan Peternakan. Bogor

Natawijaya, Arnesto dan Jarmani. 2006. Reproductive performance of female lokal chicken breeder under vitamin $\mathrm{E}$ supplementation. Animal Production, $8(2): 78-82$.

Nurfirman. 2011. Efektivitas medium Beltsvile Poultry Semen Extender (BPSE) terhadap kualitas semen cair ayam lokal. Skripsi. Fakultas Kedokteran Hewan. Institut Pertanian Bogor. Bogor.

Nishida, T., K. Nozawa, K. Kondo, S.S. Mansjoer and H. Martojo. 1980. Morphological and Genetikal Studies on the Indonesia in Native Fowl. The Research Group of Overseas Sci. Survey. P.47-70.

Pattison, M. 1993. The Health of Poultry. Longman Scientific and Technical.

Prasetyo, S., I.D.P. Winata, Lestari dan K.A Haryanto. 2002. Kajian Fenotipe Produksi Ayam Kampung, Ayam Arab dan Hasil Persilangannya. Laporan Penelitian. BPTP-Universitas Mataram. Mataram.

Prawirodigdo, S., D. Pramono, Ernawati, B. Budiharto, P. Lestari, Sugiono, G. Sejati, Prawoto, S. Iskandar dan D. Zaenudin. 2001. Pengkajian Partisipatif Persilangan Ayam Pelung $x$ Ayam Ras Petelur dan Ayam Lokal. Laporan Hasil Pengkajian. BPTP Jawa Tengah.

Putri, A., S. Darwati dan Rukmiasih. 2014. Performa Penetasan Telur Ayam Hasil Persilangan Ayam Kampung dengan Ayam Ras Pedaging. Skripsi. Fakultas Peternakan. Institut Pertanian Bogor. Repository IPB. Bogor

Rukmana, R. 2003. Ayam Buras. Penerbit Kanisius. Yogyakarta.

Sastrodihardjo, S. 1996. Inseminasi Buatan pada Ayam Buras. Leaflet, Cetakan Kedua Balitnak, Puslitbang Peternakan Bogor.

Sastrodihardjo, S, 1996. Inseminasi Buatan Pada Ayam Buras. Leaflet, Cetakan Kedua Balitnak, Puslitbang Peternakan Bogor.

Sopiyana, S., S. Iskandar, T. Susanti dan D. Yogaswara. 2006. Pengaruh Krioprotektan DMA, DMF dan Glycerol pada Proses Pembekuan Semen Ayam Kampung. Seminar Nasional Teknologi Peternakan dan Vet.

Srigandono, B. 1997. Produksi Unggas Air. Gajah Mada University Press, Yogyakarta. 
Srivin, .S Dako dan F. Ilham. 2016. Korelasi ukuran-ukuran Tubuh Ayam kampung di Pesisir Pantai Selatan Kabupaten Bone-Bolango Provinsi Gorontalo. Jurnal Belibis Sains. 1 : 717

Toelihere, M.R. 1985. Fisiologi Reproduksi pada Ternak. Penerbit Angkasa. Bandung.

Wardiny. 2002. Evaluasi Hubungan antara Indeks Bentuk Telur dengan Prosentase Telur yang Menetas pada Ayam Lokal Galur Arab. Lembaga Penelitian. Universitas Terbuka. Jakarta.
Warwick, E.J., J.M. Astuti dan W. Hardjosubroto, 1990. Pemuliaan Ternak. Gadjah Mada University Press, Yogyakarta Hardjosubroto, W., 1994. Aplikasi Pemuliabiakan Ternak di Lapangan. Gramedia Widiasarana Indonesia, Jakarta.

Wineland, M. 2000. Moisture loss in hatching eggs. Abor acres, Service Bulletin No. 14 July 15. 